\title{
First Record of Eutypella parasitica on Maples in Urban Area in Croatia
}

\author{
Dario Ivići ${ }^{*}$, Zdravka Sever ${ }^{1}$, Željko Tomić ${ }^{1}$
}

(1) Croatian Centre for Agriculture, Food and Rural Affairs - Institute for Plant Protection, Gorice 68b, HR-10000 Zagreb, Croatia

*Correspondence: e-mail: dario.ivic@hcphs.hr
Citation: IVIĆ D, SEVER Z, TOMIĆ Ž 2017 First Record of Eutypella parasitica on Maples in Urban Area in Croatia. Southeast Eur for 8 (1): 47-50. DOI: https://doi. org/10.15177/seefor.17-02

Received: 28 Dec 2016; Revised: 27 Jan 2017; Accepted: 30 Jan 2017; Published online: 24 Feb 2017

\begin{abstract}
Background and Purpose: Eutypella parasitica, a plant pathogenic fungus attacking maples (Acer spp.) was detected for the first time in Croatia in 2007. From 2007 to 2014, it was found only in forests, on several trees in Hum na Sutli, near Slovenian border. In 2015, the presence of Eutypella parasitica was monitored for the first time in urban areas.

Materials and Methods: Within the official survey programme, 23 visual surveys were conducted and 24 samples were collected and analysed for the presence of fungi. E. parasitica was found in Bundek Park in Zagreb. Typical symptoms of Eutypella canker were detected on two field maples (Acer campestre) and two boxelder maples (Acer negundo). Twelve isolates were collected from symptomatic trees.

Conclusions: Eleven out of twelve isolates from four trees were confirmed as $E$. parasitica by species-specific polymerase chain reaction. This is the first report of E. parasitica in Zagreb, the first record of E. parasitica in Croatia outside forests, as well as a record of a new host species in Croatia, boxelder maple (A. negundo). Introduction pathway of $E$. parasitica in Zagreb remains unknown.
\end{abstract}

Keywords: Eutypella canker, survey, Acer campestre, Acer negundo

\section{INTRODUCTION}

Eutypella canker is a disease of maples (Acer spp.) caused by the fungus Eutypella parasitica R. W. Davidson \& R. C. Lorenz [1]. The disease is present in North America and it was not known to occur in Europe until 2005, when it was recorded in Ljubljana, Slovenia [2]. It was subsequently discovered in Austria in forests in 2006 on sycamores (Acer pseudoplatanus L.) [3]. In Croatia, E. parasitica was found for the first time in 2007 on field maples (Acer campestre L.) in Prišlin (KrapinaZagorje County), near Slovenian border [4]. In 2016, the fungus was reported in Germany [5] and Hungary [6].

Novak Agbaba et al. [7] stated that E. parasitica is not a quarantine plant pathogen within the European Union, and the damaging potential of this alien fungal species in Europe is largely unknown [7]. Further spread of E. parasitica in Croatian forests could damage populations of different valuable maple species, causing economic loss [7]. According to the risk analysis by Ogris et al. [8], Croatia is considered to be a state where the risk of $E$. parasitica spread is high. These were the main reasons why $E$. parasitica was an object of official survey programmes, conducted in forests from 2011 to 2015. The review of the current situation of E. parasitica in Croatia showed that only two out of 2029 maple trees inspected during four years of survey were found infected with $E$. parasitica, both located in forests around Hum na Sutli [7].

In 2015, the presence of E. parasitica was monitored for the first time in urban areas, with the continuation of monitoring activities in forests. The main aim of the monitoring programme in urban areas was to contribute to the knowledge on the presence and distribution of this alien plant pathogen in Croatia.

\section{MATERIALS AND METHODS}

Twenty-three visual surveys of maple trees were carried out from the middle of May to the end of October in 2015. Surveys were carried out in parks, alleys, streets and public green areas, where maple trees were visually inspected for 
the presence of Euytpella canker symptoms. Sycamores, field maples, boxelder maples (Acer negundo L.), Norway maples (Acer platanoides L.), silver maples (Acer saccharinum L.) and Tatarian maples (Acer tataricum L.) were the tree species examined. One survey was carried out on maple trees in Poreč (12 trees examined), Virovitica (52 trees examined), Koprivnica (43 trees examined), Desinec (20 trees examined), Osijek (70 trees examined), Beli Manastir (21 trees examined), Novska (24 trees examined), Čakovec (39 trees examined), Varaždin ( 59 trees examined) and Metković (11 trees examined). Eleven surveys were conducted in different periods in nine districts of the City of Zagreb, with a total of 187 maple trees examined.

Trees were examined for the presence of cankers with similar symptoms to Eutypella canker. When cankers on the main trunk were discovered, bark at the edge of the canker was removed or peeled off to check for the eventual presence of white mycelium fans beneath. The surface of cankers was examined with magnifying lens to determine the eventual presence of black protruding pertihecial necks. Fragments of wood from the edge of necrotic areas or wood fragments with pieces of bark from the cankers were collected for laboratory analysis. If white mycelial mats beneath the cankers were noted, their fragments were cut out and collected as the additional sub-samples. Multiple sub-samples were taken from each tree showing symptoms, and one tree was considered as one sample. Twenty-four samples were collected, 17 from the City of Zagreb, two from Osijek and one each from Desinec, Beli Manastir, Novska, Čakovec and Varaždin.

Laboratory analyses were carried out at the laboratory for mycology of the Institute for Plant Protection, Zagreb. Wood fragments were cut into chips (approximately $5 \times 5$ $\mathrm{mm})$, surface-sterilized for one minute in $1 \% \mathrm{NaOCl}$, rinsed with sterile water, inoculated on potato-dextrose agar (PDA) and incubated at $22^{\circ} \mathrm{C}$ in darkness. Isolation from mycelial mats was performed by peeling small pieces of mycelia with a needle and placing them directly on PDA. If developed after incubation, sterile white mycelial colonies were sub-cultured in pure cultures from the edge of the advancing growth.

Among the fungi isolated from samples, 12 isolates from four samples resembled descriptions of $E$. parasitica in pure cultures $[1,7,9]$. Polymerase chain reaction (PCR)-based method and species-specific primer pair (EpR/EpF) developed by Piškur et al. [10] were used for the identification of isolates. Total DNA from the cultures was extracted from the mycelium ground in liquid nitrogen using Extract-N-Amp ${ }^{\circledR}$ Plant PCR Kit (Sigma-Aldrich) according to the manufacturer's instructions. PCR mixture and PCR conditions were similar to Piškur et al. [10]. Isolates which yielded amplification fragments of $341 \mathrm{bp}$ were identified as $E$. parasitica.

All isolates confirmed as E. parasitica are stored at the Institute for Plant Protection in Zagreb.

\section{RESULTS AND DISCUSSION}

Declining maple trees were noted on all locations surveyed, but trees with cankers on the main trunk were recorded only in the City of Zagreb, Osijek, Desinec, Beli Manastir, Novska, Čakovec and Varaždin. Typical symptoms of Eutypella canker were observed on two field maple trees and on two boxelder maple trees in Bundek Park in Zagreb. On other locations, cankers were different from those described to be caused by E. parasitica, although bark cracking and callus formation were visible on trees affected. However, no characteristic white mycelial mats were found beneath the bark of such trees. Fungi belonging to Botryosphaeriaceae family were isolated from such samples.

In Bundek Park, "cobra neck" symptom with large swollen old canker $45 \mathrm{~cm}$ wide and $120 \mathrm{~cm}$ long was visible on the trunk of one field maple tree (Figure 1), while distorted trunk growth around the canker $(25 \times 58 \mathrm{~cm})$ was evident on the other symptomatic field maple. Similar cankers were noted on two boxelder maples, typically sunken, swollen and also evident on the main trunk (Figure 2), but notably smaller $(30 \times 38 \mathrm{~cm}$ and $26 \times 25 \mathrm{~cm})$. Mats of white mycelium were visible after removing bark layers at the edge of the cankers (Figure 3). The fungus was readily isolated from both mycelial mats placed directly on PDA, or from the wood tissue chips cut from the edge of the advancing mycelial mats. Twelve isolates were collected from the trees with typical Eutypella canker symptoms. Their colonies on PDA were white and sterile, and all 12 cultures were morphologically similar. Among 12 isolates, 11 yielded 341-bp fragments reported to be specific for E. parasitica [10]. Nine isolates originated from field maples, while the remaining two were isolated from boxelder maples.

E. parasitica was isolated from and confirmed in four trees with typical symptoms, but the number of infected maple trees in Bundek Park may be higher. Bark cracking and possible initial phases of canker development were observed

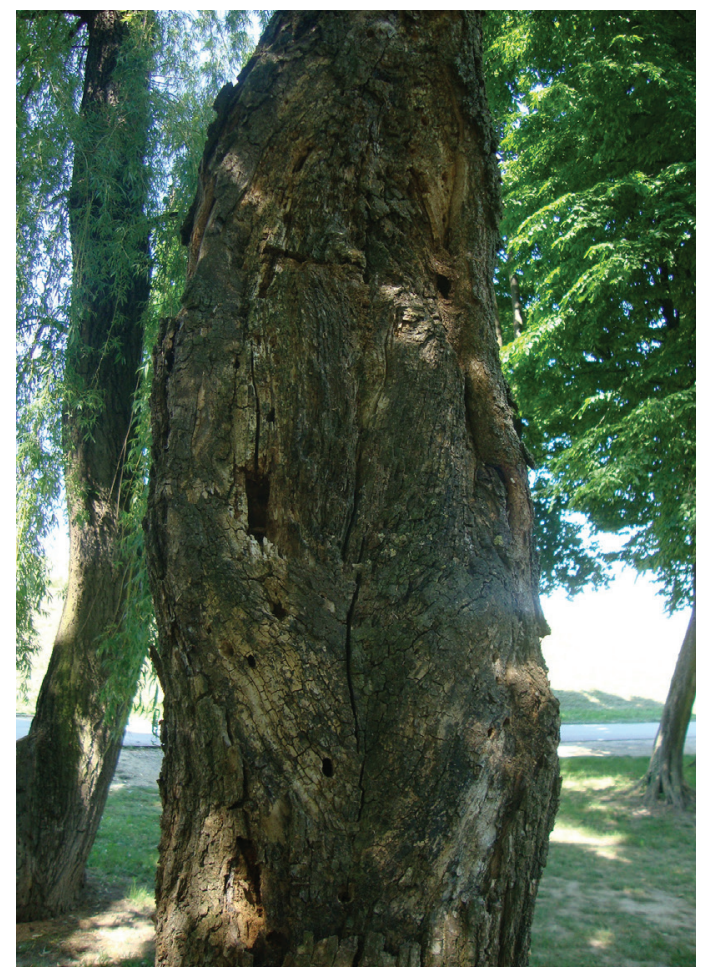

FIGURE 1. Large canker on a field maple tree 




FIGURE 2. Eutypella canker on a boxelder maple tree

on other field maples, sycamores and Tatarian maples within the park. Such trees were not sampled.

Introduction pathway of $E$. parasitica in Zagreb is unknown, but it may be independent of its introduction to the forests around Hum na Sutli. Considering the slow development of Eutypella canker symptoms [7] and the appearance of very large canker on one infected field maple in Bundek Park, the disease has probably been present in the park for decades, as speculated by Cech et al. [5], who described the situation with Eutypella canker of maples in Germany. From the initial focus, after E. parasitica perithecia develop on an infected tree, the disease may continue to spread to nearby susceptible hosts.

Finding of $E$. parasitica in urban area reflects the risk of introduction of alien, new forest pests and pathogens into urban areas, from where these harmful organisms could spread to forests causing long-term losses. Cases of Asian longhorn beetle (Anoplophora chinensis), redneck longhorn beetle (Aromia bungii) or thousand cankers disease (Geosmithia morbida) are clearly showing such risks [11-13]. In different European countries, all these quarantine and nonquarantine alien harmful organisms were found in gardens

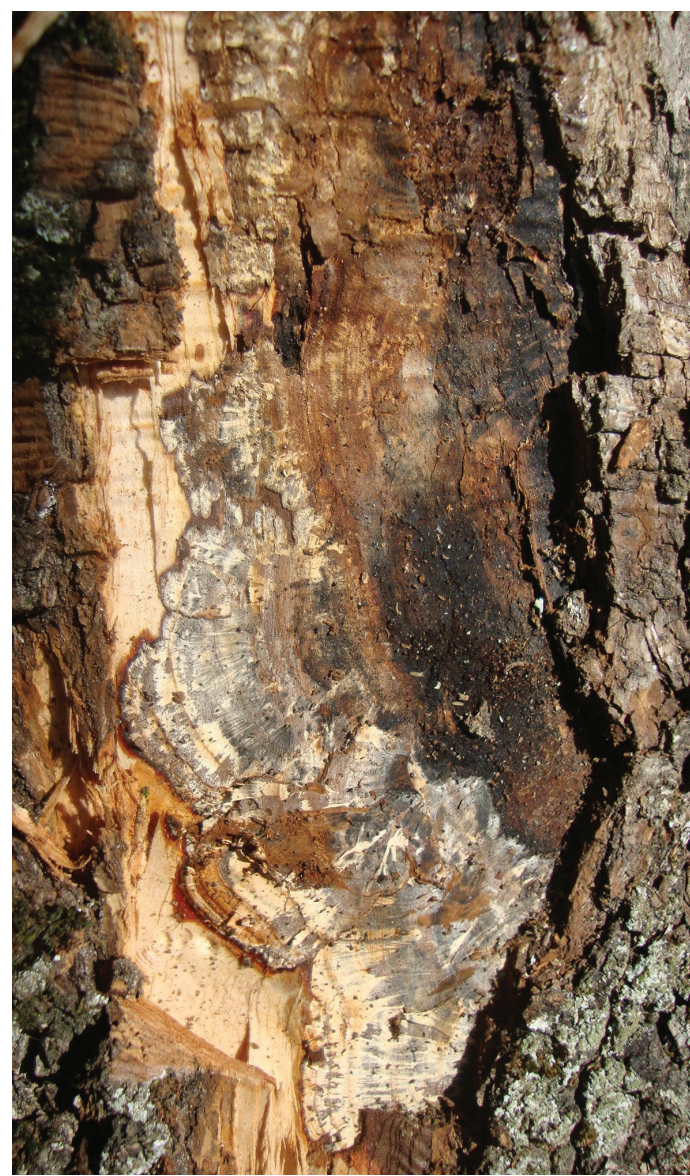

FIGURE 3. White mycelial fans beneath the bark of field maple

in urban areas [11-13] where they can establish their initial populations if efficient phytosanitary measures are not taken. Alien forest pests and pathogens can be introduced from plants imported from all over the world and distributed as "ornamental" or "horticultural" woody plants. The analysis of 123 invasive forest pathogens in Europe has shown that 38\% of these organisms have been found on ornamental trees in parks and gardens, while $36 \%$ have been found in forests [14]. Trade was indicated to be among the most common pathways of the introduction and diffusion of invasive forest pathogens [14]. Early detection of an invasive forest pathogen and the investigation of pathways for its introduction and spread seem to be the only measures for finding a strategy to prevent this kind of biological invasions [14].

\section{CONCLUSIONS}

Finding of E. parasitica in Zagreb is the first record of this fungus in an urban area in Croatia. Boxelder maple is a new host species recorded for E. parasitica in Croatia, beside previously reported field maple and sycamore [6]. 


\section{REFERENCES}

1. DAVIDSON RW, LORENZ RC 1938 Species of Eutypella and Schizoxylon associated with cankers of maple. Phytopathology 28: 733-745

2. JURC D, OGRIS N, SLIPPERS B, STENLID J 2006 First report of Eutypella canker of Acer pseudoplatanus in Europe. Plant Pathol 55 (4): 577. DOI: https://doi.org/10.1111/i.13653059.2006.01426.x

3. CECH TL 2007 First record of Eutypella parasitica in Austria (in German with English summary). Forstsch Aktuell 40: 10-13

4. OGRIS N, DIMINIĆ D, PIŠKUR B, KRAIGHER H 2008 First report of Eutypella parasitica causing cankers on field maple (Acer campestre) in Croatia. Plant Pathol 57 (4): 785. DOI: https://doi.org/10.1111/i.1365-3059.2008.01869.x

5. CECH TL, SCHWANDA K, KLOSTERHUBER M, STRAßER L, KIRISITS T 2016 Eutypella canker of maple: first report from Germany and situation in Austria. Forest Pathol 46 (4): 336340. DOI: https://doi.org/10.1111/efp.12268

6. JURC D, OGRIS N, PIŠKUR B, CSÓKA G 2016 First report of Eutypella canker of maple (Eutypella parasitica) in Hungary. Plant Dis 100 (6): 1241. DOI: https://doi.org/10.1094/ PDIS-11-15-1283-PDN

7. NOVAK AGBABA S, ĆELEPIROVIĆ N, KARIJA VLAHOVIĆ M, LIOVIĆ B 2015 Eutypella parasitica R.W. Davidson \& R.C. Lorenz seven years after the first findings in Croatia (in Croatian with English summary). Sumar list 139 (5-6): 263271
8. OGRIS N, JURC D, JURC M 2006 Spread risk of Eutypella canker of maple in Europe. Bulletin OEPP EPPO Bull 36 (3): 475-485. DOI: https://doi.org/10.1111/j.13652338.2006.01047.x

9. TROUILLAS FP, GUBLER WD 2010 Pathogenicity of Diatrypaceae species in grapevines in California. Plant Dis 94 (7): 867-872. DOI: https://doi.org/10.1094/PDIS-94-7$\underline{0867}$

10. PIŠKUR B, OGRIS N, JURC D 2007 Species-specific primers for Eutypella parasitica, the causal agent of Eutypella canker of maple. Plant Dis 91 (12): 1579-1584. DOI: https:// doi.org/10.1094/PDIS-91-12-1579

11. MONTECCHIO L, FACCOLI M 2014 First record of thousand cankers disease Geosmithia morbida and walnut twig beetle Pityophthorus juglandis on Juglans nigra in Europe. Plant Dis 98 (5): 696. DOI: https://doi.org/10.1094/PDIS10-13-1027-PDN

12. GARONNA AP, NUGNES F, EPINOSA B, GRIFFO R, BENCHI D 2013 Aromia bungii, a new Asian worm found in Campania (in Italian with English summary). Inf Agrar 69: 60-62

13. TOMICZEK C, HOYER-TOMICZEK U 2007 Asian Longhorned Beetle (Anoplophora glabripennis) and Citrus Longhorned Beetle (Anoplophora chinensis) in Europe - Actual Situation (in German with English summary). Forstsch Aktuell 38: 2-5

14. SANTINI A, GHELARDINI L, DE PACE C, DESPREZ-LOUSTAU ML, CAPRETTI P, CHANDELIER A, CECH T, CHIRA D, et al. 2013 Biogeographical patterns and determinants of invasion by forest pathogens in Europe. New Phytol 197 (1): 238-250. DOI: https://doi.org/10.1111/i.14698137.2012.04364.x 